\title{
Letter to the Editor: Isethionic Acid and Milk
}

\author{
MOHAMED A. REMTULLA AND DEREK A. APPLEGARTH ${ }^{(3)}$ \\ Biochemical Diseases Laboratory, Childrens Mospital, Vancouver, Canada \\ JOHN A. STURMAN AND GERALD E. GAULL \\ De $c^{\prime}$ artment of Human Development and Genetics, Institute of Basic Research in Mental Retardation, Staten Island, \\ and Department of Pediatrics, Mount Sinai School of Medicine of The City University of New York, New York, \\ New York, USA
}

We recently reported that $\left[{ }^{35} \mathrm{~S}\right]$ taurine injected into lactating rats was transferred via the milk to the pups (2). In this report we noted the presence of another radioactive compound besides taurine which was present only in extracts of milk and which cochromatographed with authentic isethionic acid. The presence of this compound in milk was puzzling and we felt that it was important to determine whether or not isethionic acid was present as a natural constituent of milk. The development of a sensitive gas-liquid chromatographic assay for isethionic acid (1) allowed us to perform such measurements on rat milk samples.

Samples of milk were obtained from lactating rats of the NelsonWistar strain, from 2 days after birth to 6 days after birth, as previously described (2). Samples of milk $(0.2 \mathrm{ml})$ were freezedried and resusp $:$ nded in $10 \mathrm{ml}$ deionized water using a glass-glass homogenizer. Authentic isethionic acid $(25-150 \mathrm{nmol})$ was added to some of the samples at this stage. The suspension was mixed with an equal volume of methanol $(10 \mathrm{ml})$ and then treated with an equal volume of Folch solvent $(20 \mathrm{ml})$, mixed thoroughly, and centrifuged to separate the layers. The aqueous layer was removed and extracted as previously described (1). Methylation with diazomethane in the presence of butane-sulfonic acid as internal standard (10 nmol/sample) was carried out as described (1). A thick white precipitate formed in the methylation mixture and was removed by centrifugation. The supernatant fluid was concentrated to $20 \mu \mathrm{l}$ under a stream of dry nitrogen and samples (3.5 $\mu \mathrm{l})$ were injected into the gas chromatograph (Bendix 2500 , ov- 17 column, $130^{\circ}$, equipped with a flame ionization detector). Isethionic acid standards of $0,25,50,100$, and $200 \mathrm{nmol}$ were used for quantification.

The samples analyzed showed no trace of isethionic acid. The recovery of authentic isethionic acid added to the milk samples was $100 \%$ and the sensitivity of the method was such that $20 \mathrm{nmol}$ isethionic acid $/ \mathrm{ml}$ milk could have been easily detected. In our earlier report, we noted that the radioactive compound in milk which cochromatographed with authentic isethionic acid comprised $30-40 \%$ of the total radioactivity (the rest of which was present as taurine). The present assay could easily have detected isethionic acid present at $10 \%$ of the taurine concentration.

We conclude that isethionic acid is not a significant constituent of rat milk (if indeed it is present at all). The radioactive compound which cochromatographed with authentic isethionic acid is either another compound or was produced by gut bacteria, reabsorbed, and secreted in the milk after the ip injection. Of note in this regard are the results of experiments designed to test the possible bioconversion of taurine to isethionic acid by slices of dog heart and rat heart. We found that $\left[{ }^{35} \mathrm{~S}\right]$ taurine was converted in up to $10 \%$ yield to a radioactive compound which behaved chomatographically like isethionic acid. The same result was obtained, however, when $\left[{ }^{35} \mathrm{~S}\right]$ taurine was added to heart slices in buffer and extracted immediately with methanol. We can detect no bioconversion of taurine to isethionic acid in heart tissue by the procedures described above for milk. It is likely that the radioactive compound detected in milk may be the same or a similar chemical to the radioactive compound detected in heart slices, but it is unlikely to be isethionic acid.

\section{REFERENCES AND NOTES}

1. Remtulla, M. A., Applegarth. D. A., Clark. D. G., and Williams, I. H.: Analysis of isethionic acid in mammalian tissues. Life Sci., 20:2029 (1977).

2. Sturman. J. A.. Rassin. D. K.. and Gaull, G. E.: Taurine in developing rat brain Transfer of $\left.{ }^{33} \mathrm{~S}\right]$ taurine to pups via the milk. Pediat. Res., 11: 28 (1977).

3. To whom correspondence should be addressed.

4. Received for publication October 5. 1977. 